
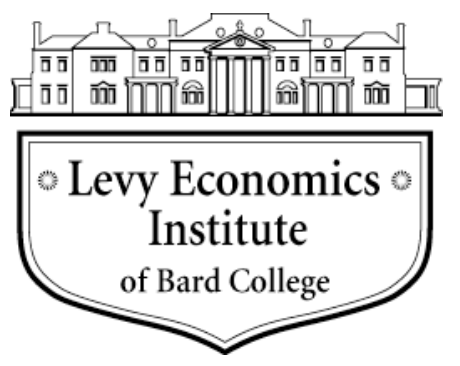

Working Paper No. 704

\title{
Imbalances? What Imbalances? A Dissenting View
}

by

\author{
L. Randall Wray \\ Levy Economics Institute of Bard College
}

January 2012

The Levy Economics Institute Working Paper Collection presents research in progress by Levy Institute scholars and conference participants. The purpose of the series is to disseminate ideas to and elicit comments from academics and professionals.

Levy Economics Institute of Bard College, founded in 1986, is a nonprofit, nonpartisan, independently funded research organization devoted to public service. Through scholarship and economic research it generates viable, effective public policy responses to important economic problems that profoundly affect the quality of life in the United States and abroad.

Levy Economics Institute

P.O. Box 5000

Annandale-on-Hudson, NY 12504-5000

http://www.levyinstitute.org

Copyright (C) Levy Economics Institute 2012 All rights reserved 


\begin{abstract}
It is commonplace to link neoclassical economics to 18th- or 19th-century physics and its notion of equilibrium, of a pendulum once disturbed eventually coming to rest. Likewise, an economy subjected to an exogenous shock seeks equilibrium through the stabilizing market forces unleashed by the invisible hand. The metaphor can be applied to virtually every sphere of economics: from micro markets for fish that are traded spot, to macro markets for something called labor, and on to complex financial markets in synthetic collateralized debt obligationsCDOs. Guided by invisible hands, supplies balance demands and markets clear. Armed with metaphors from physics, the economist has no problem at all extending the analysis across international borders to traded commodities, to what are euphemistically called capital flows, and on to currencies themselves. Certainly there is a price, somewhere, somehow, that will balance supply and demand. The orthodox economist is sure that if we just get the government out of the way, the market will do the dirty work. The heterodox economist? Well, she is less sure. The market might not work. It needs a bit of coaxing. Imbalances can persist. Market forces can be rather impotent. The visible hand of government can hasten the move toward balance.
\end{abstract}

Orthodox economists as well as most heterodox economists see the Global Financial Crisis as a consequence of domestic and global imbalances. The most common story blames the US Federal Reserve for excessive monetary ease that spurred borrowing, and the US fiscal and trade imbalances for a surplus of liquidity sloshing around global financial markets. Looking to the specific problems in Euroland, the imbalances are attributed to profligate Mediterraneans. The solution is to restore global balance, which requires some combination of higher exchange rates for the Chinese, reduction of US trade deficits, and Teutonic fiscal discipline in the United States, the UK, and Japan, as well as on the periphery of Europe.

This paper takes an alternative view, following the sectoral balances approach of Wynne Godley, combined with the modern money theory (MMT) approach derived from the work of Innes, Knapp, Keynes, Lerner, and Minsky. The problem is not one of financial imbalance, but rather one of an imbalance of power. There is too much power in the hands of the financial sector, money managers, the predator state, and Europe's center. There is too much privatization and pursuit of the private purpose, and too little use of government to serve the public interest. 
In short, there is too much neoliberalism and too little democracy, transparency, and accountability of government.

Keywords: Global Imbalances; Sectoral Balances Approach; Modern Money Theory; Debt Cancellation; Global Financial Crisis; Euro Crisis; EMU; State Theory of Money; Functional Finance

JEL Classifications: E12, E32, E42, E52, E62, E63, F02, F32, F33, F34, F36, G15, H6 


\section{INTRODUCTION}

It is commonplace to link neoclassical economics to 18th- or 19th- century physics with its notion of equilibrium, of a pendulum once disturbed eventually coming to rest. Likewise, an economy subjected to an exogenous shock seeks equilibrium through the stabilizing market forces unleashed by the invisible hand. The metaphor can be applied to virtually every sphere of economics: from micro markets for fish that are traded spot, to macro markets for something called labor, and on to complex financial markets in synthetic collateralized debt obligationsCDOs.

Guided by invisible hands, supplies balance demands and all markets clear. Armed with metaphors from physics, the economist has no problem at all extending the analysis across international borders to traded commodities, to what are euphemistically called capital flows, and on to currencies, themselves. Certainly there is a price, somewhere, somehow, that will balance supply and demand-for the stuff we can drop on our feet to break a toe, and on to the mental and physical efforts of our brethren, and finally to notional derivatives that occupy neither time nor space.

It all must balance, and if it does not, invisible but powerful forces will accomplish the inevitable. The orthodox economist is sure that if we just get the government out of the way, the market will do the dirty work. Balance. The market will restore it and all will be right with the world.

The heterodox economist? Well, she is less sure. The market might not work. It needs a bit of coaxing. Imbalances can persist. Market forces can be rather impotent. The visible hand of government can hasten the move to balance.

Balance is nice; it’s intuitively appealing. In truth, it was not invented by physics. All cultures view it as natural. It is the universal condition-both in nature and in human society. It reflects an inner yearning for fairness. As Margret Atwood (2008) explains, all human and ape societies have recognized the law of reciprocity-you will pay back in this life or the next. There is an innate notion of equivalent values, and therefore of balances. Animals can tell "bigger than" and they revolt when they are shorted. Even the rat knows it's not fair. She goes on strike if you try to reduce the reward for running a maze. That violates the rat notion of balance. 
There is a right way to do things. Failure to follow tradition upsets the balance. Who knows what wrath imbalance might invoke among the gods? Gabriel, the Angel of records, keeps God's ledger book — to be produced in the Last Judgment. Too much imbalance in your life and you go to hell. Muslims refer to the scales of justice-your good deeds are weighed against the bad ones. There is a balancing out-you might just tip the scales. Much earlier, the God of Time was a Scribe as well as the God of Measurement and Engineering-how would you like that job description? He kept the records, measured worth, and built the scales. At death, he weighed your heart to assess your value (Atwood 2008). The Pope, or Pontiff, came out of the engineering gens of one of the Tribes of Rome-that built all the bridges, or ponte, over the Tiber river and followed the example set by the engineers of the Nile by becoming the priestly upper class (Wray 2004).

Time. Measurement. Balance. Everything you need for money and accounting.

And of course none of you is debt-free-Eve's original sin ensures that from birth. Can you redeem yourself? Not likely. You need help. So from time immemorial debts would be periodically cancelled - the Year of Jubilee. With every change of ruler (who of course, was an earthly God of Measurement) or every seven years or 30 years depending on sinfulness, all debts were cancelled. Babylonia chose 30 as the likely reign of a ruler; the Bible chose 7—the lucky number, a 7-year ever-normal granary would get you through a drought.

Debt cancellation. Why? These were no bleeding heart liberals. No, debt cancellation was to restore balance. If all your subjects are in hock to creditors, you cannot rule them. So you eat their sins, redeem their debts, free them and their wives and kids from debt bondage.Hallelujah!

Now why do we need periodic debt cancellation? The Soddy principle (after Frederick Soddy, the radiochemist). Compound interest trumps compound growth. As Michael Hudson (1998) says, humans recognized this even before they invented writing. The earliest textbooks showed how to calculate compound interest. It was our first imbalance-our first violation of natural law. It would inevitably lead to concentration of wealth-like the game of Monopoly, the last player standing would take all. So from Babylonia to Rome, balance was restored by cancelling debts. Time was circular: time and accounts would reset at zero when the slate was 
wiped clean. Time and debt are inherently related. Time compounds the debts at the rate of interest. In Heaven there are no debts and no time; in Hell all debts are compounded forever. Redemption allows time and debt to start over from balance. But with Roman Law we abolished circular time. Henceforth, it moved in one direction only—from a largely known past to what Paul Davidson (1978) would call a fundamentally uncertain future. No more debt cancellations. Just debtor's prisons - where the debtor would be held until family could redeem him. Later we used prisons and execution simply for retribution—an eye for an eye, a life for a life, so that the scales would balance. But debtor's prisons destroyed the balance between creditors and sovereign— - just as debt bondage had several thousand years earlier. With the family head in prison, it was impossible to repay. Again, bankruptcy was invented not out of compassion but to restore the balance between the rights of rulers and of creditors. Yet bankruptcy only allowed a partial reset. It was a poor substitute for Jubilee and Hallelujah. And the creditors ran the show. They liked inequality; they liked imbalance.

As Kenneth Boulding used to say, surveys of the rich consistently show that you cannot imagine how incredibly greedy they are, and how monumentally stupid they are, too. They will gleefully roast the goose that lays the golden egg. If you do not believe that, you have not been watching Wall Street over the past decade. Or what Germany is doing to Greece and Ireland. When creditors have too much power, they destroy the balance.

\section{MODERN MONEY}

Let's bring this to the present. Credit and debt are two sides of the same coin. Both creditor and debtor are sinful. They balance. Exactly. The balance is ensured by double-entry book-keeping. Redemption frees both creditor and debtor. It results in a different balance-one without sin. Bankruptcy also results in balance, but one that maintains the power of creditor over debtor-at least within the limits of law.

But the point is, debts and credits are always in balance. In the private sector, as we always say, inside debts net to zero. Balance. When we include a government, its IOUs are balanced by credits held by the nongovernment sector. The nongovernment sector's net credits are claims on government. The government's deficit means a nongovernment surplus. It 
balances. And when we include an external sector, a domestic deficit must be balanced by a foreign surplus. It, too balances.

There is always financial balance. Imbalance can arise only due to arithmetic errors. Looking at our global mess as a financial imbalance — as almost everyone does—is a mistake. Our mess is not due to excess liquidity sloshing around the world in the mid 2000s. It is not due to excessive borrowing by America from the Chinese. And it is not due to profligate spending by Mediterraneans with too little self-control.

We need to look at this the way Babylonia's rulers saw it. The problem is a balance of power, not an imbalance of finance. And to understand this, we've got to understand what money is. We need to return to Keynes’s Treatise on Money. Many of you have heard me talking about Keynes's State Theory of Money for the past 20 years. I've got nothing new to say about it. What we now call modern money theory (MMT) is out there-in academic publications, in policy notes, and all over the blogosphere. It combines the insights of Knapp (1924), Keynes (1976 [1930], 1914), Innes (1913, 1914), Lerner (1943, 1947), Minsky (1986), Godley (1996), Ingham (2000, 2004a, 2004b) and Goodhart (1998, 2008). (Also see Wray 1990, 1998, 2004.)

To greatly simplify, money is a measuring unit, originally created by rulers to value the fees, fines, and taxes owed. By putting the subjects or citizens into debt—original sin—real resources could be moved to serve the public purpose. Taxes drive money. This is why money is always linked to sovereign power-the power to command resources. That power is rarely absolute. It is contested, with other sovereigns but often more important is the contest with domestic creditors. Too much debt to private creditors reduces sovereign power-it destroys the balance of power needed to govern.

So, money was created to give government command over socially created resources.

First we need to note that the money of account is many thousands of years old — at least four millennia old and probably much older. (The "modern” in "modern money theory” comes from Keynes’s claim that money has been state money for the past 4000 years, “at least.”) We know this because we have, for example, the clay tablets of Mesopotamia that record values in money terms, along with price lists in that money of account. 
We also know that money’s earliest origins are closely linked to debts and recordkeeping, and that many of the words associated with money and debt have religious significance: debt, sin, repayment, redemption, “wiping the slate clean,” and Year of Jubilee. In the Aramaic language spoken by Christ, the word for "debt” is the same as the word for "sin." The "Lord's Prayer" that is normally interpreted to read "forgive us our trespasses" could be just as well translated as “our debts” or “our sins”—or as Atwood (2008) says, “our sinful debts.”

Records of credits and debits were more akin to modern electronic entries-etched in clay rather than on computer tapes. And all known early money units had names derived from measures of the principal grain foodstuff-how many bushels of barley equivalent were owed, owned, and paid. All of this is more consistent with the view of money as a unit of account, a representation of social value, and an IOU rather than as a commodity. Or, as we MMers say, money is a "token," like the cloakroom “ticket” that can be redeemed for one's coat at the end of the operatic performance. However, government’s IOUs are “redeemed” for taxes (Knapp 1924; Innes 1913, 1914; Wray 2004).

Indeed, the "pawn” in pawnshop comes from the word for "pledge,” as in the collateral left, with a token IOU provided by the shop that is later "redeemed" for the item left. St. Nick is the patron saint of pawnshops (and, appropriately, for thieves who pawn their stolen goods), while “Old Nick” refers to the devil (hence, the red suit and chimney soot—and "to nick” means to steal) to whom we pawn our souls (Atwood 2008). The Tenth Commandment's prohibition on coveting thy neighbor's wife (which goes on to include male or female slave, or ox, or donkey, or anything that belongs to your neighbor) originally had nothing to do with sex and adultery but rather with receiving them as pawns for debt (Hudson 1998).

We all know Shakespeare's admonition "neither a borrower nor a lender be”-as religion typically views both the "devil” creditor and the debtor who "sells his soul” by pawning his wife and kids into debt bondage as sinful —if not equally then at least simultaneously tainted, united in the awful bondage of debt. And, as we know, Lucifer records the debts_-of the souls he will collect. He'll sell you a good time now, but your soul lies in the balance. You buy now, you pay forever. Sort of like Student Loans in America.

Of course, for most of humanity today the original sin/debt is to the tax collector, because as they say, the only things in life you cannot escape are death and taxes. Old Nick has 
a lock on both of those - the tax collector who calls at death. It is said that only death can "wipe the slate clean" as "death pays all debts;" however, once your soul is sold, there is no balance because hell is the roach motel-you've checked in and you will never get out. But Christ is the redeemer-he's a sin eater, repaying your debts to restore balance, to let you sinners get to heaven.

In the beginning we had the clay tablets of Mesopotamia recording debits and credits in the Temple's grain unit of account and then the Palace's money of account for the first few millennia after money was invented as a universal measure of our multiple and heterogeneous sins. The first coins were created thousands of years later, in the greater Greek region (so far as we know, in Lydia in the $7^{\text {th }}$ century BC). And in spite of all that has been written about coins, they have rarely been more than a very small proportion of the "money things" involved in finance and debt payment. For most of European history, for example, tally sticks, bills of exchange, and "bar tabs" (kept with chalk upon slate behind the bar-again, the reference to "wiping the slate clean" is revealing, something that might not be done for a year or two at the pub, where the alewife kept the accounts) did most of that work.

Until recent times, most payments made to the Crown in England were in the form of tally sticks (the King's own IOU, recorded in the form of notches in hazelwood) - whose use was only discontinued well into the $19^{\text {th }}$ century (with a catastrophic result: the Exchequer had them thrown into the stoves with such zest that Parliament was burnt to the ground by those devilish tax collectors!) In most realms, the quantity of coin was so small that it could be (and was) frequently called in to be melted for re-coinage. (If you think about it, calling in all the coins to melt them for re-coinage would be a very strange and pointless activity if coins were already valued by embodied metal!)

So what were coins and why did they contain precious metal? To be sure, we do not know. Money's history is "lost in the mists of time when the ice was melting... when the weather was delightful and the mind free to be fertile of new ideas-in the islands of the Hesperides or Atlantis or some Eden of Central Asia” as Keynes put it (Keynes 1976 [1930]). We have to speculate.

One hypothesis about early Greece (the presumed mother of both democracy and coinage-almost certainly the two are linked in some manner) is that the elites had nearly 
monopolized precious metal, which was important in their social circles, tied together by "hierarchical gift exchange.” They were above the agora (market place) and hostile to the rising polis (democratic city-state government). According to Classical scholar Leslie Kurke (1999), the polis first minted coin to be used in the agora to "represent the state's assertion of its ultimate authority to constitute and regulate value in all the spheres in which general-purpose money operated... Thus state-issued coinage as a universal equivalent, like the civic agora in which it circulated, symbolized the merger in a single token or site of many different domains of value, all under the final authority of the city.” The use of precious metals was a conscious thumbing-of-the-nose against the elite who placed great ceremonial value on precious metal. By coining their precious metal, for use in the agora's houses of prostitution by mere common citizens, the polis sullied the elite's hierarchical gift exchange-appropriating precious metal, and with its stamp asserting its ultimate authority.

As the polis used coins for its own payments and insisted on payment in coin, it inserted its sovereignty into retail trade in the agora. At the same time, the agora and its use of coined money subverted hierarchies of gift exchange, just as a shift to taxes and regular payments to city officials (as well as severe penalties levied on officials who accepted gifts) challenged the "natural" order that relied on gifts and favors. As Kurke argues, since coins are really nothing more than tokens of the city's authority, they could have been produced from any material. However, because the aristocrats measured a man's worth by the quantity and quality of the precious metal he had accumulated, the polis was required to mint high quality coins, unvarying in fineness. (Note that gold is called the noble metal because it remains the same through time, like the king; coined metal needed to be similarly unvarying.) The citizens of the polis by their association with high quality, uniform, coin (and in the literary texts of the time, the citizen's "mettle" was tested by the quality of the coin issued by his city) gained equal status; by providing a standard measure of value, coinage rendered labor comparable, and in this sense, coinage was an egalitarian innovation.

From that time forward, coins commonly contained precious metal. Rome carried on the tradition, and Kurke's thesis is consistent with the statement of St. Augustine, who declared that just as people are Christ's coins, the precious metal coins of Rome represent a visualization of imperial power-inexorably doing the emperor's bidding just as the reverent do Christ's. 
(“...Christ's coin is man. In him is Christ's image, in him Christ's Name, Christ's gifts, Christ's rules of duty.”)

Later, Roman coins also contained precious metal. But Roman law adopted what is called "nominalism"- the nominal value of the coin is determined by the authorities, not by the value of embodied metal in the coin (termed "metalism”).* The coin system was well-regulated and although precious metal content changed across coinages, there was no significant problem with debasement or inflation. In Roman law, one could deposit a sack of particular coins (in sacculo) and when repaid demand the same coins to be returned (vindication). However, if one were owed a sum of money (rather than specific coins), one had to accept in payment any combination of coins tendered that were "money of the realm"—officially sanctioned coins with payment enforced in court (condictio).

This practice continued through the early modern period, in which one deposited for safe keeping either sealed sacks of coins (and could demand exactly the same coins back in the stillsealed bag) or loose coins (in which case, any legal coins had to be accepted). Hence, "nominalism" prevailed in the general case, although what appears to be a form of "metalism" applied to specific coins in sacculo.* In reality, it had more to do with the view that coins were a "moveable chattel", something the owner had a property interest in. However, once the owner's loose coins were mixed with other coins, there was "no earmark"-no way of determining specific ownership, and hence the claimant only had a claim to be repaid in legal money-the legalis moneta Angliae, for example in England, which was stipulated to be a sum of "sterlings." There was no sterling coin (indeed, England did not even coin the Pound at that time, its money of account), rather, the debt was paid up by providing the appropriate sum of coins declared lawful money by the Crown—and could include foreign coins—at the nominal value dictated by the King.

The author ${ }^{1}$ ities that issued coins were free to change the metal content at each coinage; penalties for refusing to accept a sovereign's coin in payment at the value stated by the sovereign were severe (often, death). Still, there is the historical paradox that when the King

\footnotetext{
* I thank Chris Desan, David Fox, and other participants of a recent seminar at Cambridge University for the discussion I draw upon here.
} 
was paid in coin (in fees, fines, and taxes), he would have them weighed-and reject or accept at lower value the coins that were low weight. If coins were really valued nominally, why bother weighing them? Why did the issuer — the King — appear to have a double standard, one nominalist, one metalist?

In private circulation, sellers also favored "heavy" coins-those that weighed more, or that were of higher fineness (more precious metal content). They certainly did not want to find themselves in the situation of trying to make payments to the Crown with low weight coins. Hence, a “Gresham’s Law” (the "bad” forces the "good” out of circulation) would operate: everyone wanted to pay in "light" coins, but to be paid in "heavy coins." There was thus obvious concern with the metal content of coins, and fairly accurate (and quite tiny) scales were manufactured and sold to weigh coins individually. This makes it appear to modern historians (and economists) that "metalism” reigned: the value of coins appears to have been determined by metal content.

And yet we see in the courts rulings indications that the law favored a nominalist interpretation: any legal coin had to be accepted. And we see Kings who imposed long prison terms, or death, for refusing any coin deemed legal. It all appears so confusing! Was it nominal or was it metal? (The sentence was usually to serve "at the King's pleasure”- - nice way of putting it! One can just imagine the King's pleasure at holding indefinitely those who refused his coins.)

The final piece of the puzzle appears to be this: until modern minting techniques were invented (including milling and stamping), it was relatively easy to "clip" coins-cut some of the metal off the edge. They could also be rubbed to collect grains of the metal. (Even normal wear and tear rapidly reduced metal content; gold coins in particular were soft. For that reason they were particularly ill-suited as an "efficient medium of exchange"-yet another reason to doubt the metalist story.)

This is why the King had them weighed to test for clipping. (As you can imagine, the penalty for clipping was also severe, including death—but it was hard to catch.) If he did not, he would be the victim of Gresham's Law; each time he recoined he would have less precious metal to work with. But because he weighed the coins, everyone else also had to avoid being on the wrong side of Gresham’s Law (or be accused of clipping). Far from being an "efficient 
medium of exchange", we find that use of precious metals set up a destructive dynamic of clipping, weighing, and punishing that would only finally be resolved with the move to paper money! (Actually, even paper is less than ideal; perhaps some readers have experienced problems getting older paper money accepted—as I did even in Italy before it adopted the Euro-due to Gresham Law dynamics. Thank goodness for computers and keystrokes and LEDs to record money values that cannot be clipped, ripped, or ruined in the washing machine.)

A King sometimes made those dynamics worse-by recanting his promise to accept his old coined IOUs at previously agreed upon values. This was the practice of "crying down" the coins (Wray 1998). Until recent times, coins did not have the nominal value stamped on themthey were worth what the King said they were worth at his "pay houses." (Take a look at early coins: they bore mythical figures or the King's likeness, but no indication of nominal value.) To effectively double the tax burden, he could announce that all the outstanding coins were worth only half as much as their previous value. Since this was the prerogative of the sovereign, holders could face some uncertainty over the nominal value. This was another reason to accept only heavy coins - no matter how much the King cried down the coins, the floor value would be equal to the value of the metallic content. Normally, however, the coins would circulate at the higher nominal value set by the sovereign, and enforced by the court and the threat of severe penalties for refusing to accept the coins at that value.

There is also one more aspect to the story. With the rise of the regal predecessors to our modern state, there were the twin and related phenomena of Mercantilism and foreign wars. Within an empire or state, the sovereign's IOUs are sufficient "money things": so long as the sovereign takes them in payment, its subjects or citizens will also accept them. Any "token" will do-it can be metal, paper, or electronic entries. But outside the boundaries of the authority, mere tokens might not be accepted at all. In some respects, international trade and international payments are more akin to barter unless there is some universally accepted "token" (like the United States dollar today). Put it this way: why would anyone in France want the IOU of France's sworn enemy, the King of England? Outside England, the King of England's coins might circulate only at the value of precious metal contained in them. Metalism as a theory might well apply as a sort of floor to the value of a King's IOU: at worst, it cannot fall in value much below gold content as it can be melted for bullion. 
And that leads us to the policy of Mercantilism, and also to the conquest of the New World. Why would a nation want to export its output, only to have silver and gold return to fill the King's coffers? And why the rush to the New World to get gold and silver? Because the gold and silver were needed to conduct the foreign wars, which required the hiring of mercenary armies and the purchase of all the supplies needed to support those armies in foreign lands. (England did not have huge aircraft to parachute the troops and supplies into France-instead they hired mainland mercenary troops and bought the supplies from the local outfitters.) There was a nice vicious circle in this: the wars were fought both by and for gold and silver!

And it made for a monetary mess in the home country. The sovereign was always short of gold and silver, hence had a strong incentive to debase the currency (to preserve metal to fund the wars), while preferring payment in the heaviest coins. The population had a strong incentive to refuse the light coins in payment, while hoarding the heavy coins. Or, sellers could try to maintain two sets of prices - a lower one for heavy coins and a high one for light coins. But that meant toying with the gallows. What a monetary mess!

The mess was resolved only very gradually with the rise of the modern nation state, a clear adoption of nominalism in coinage, and—finally—with abandonment of the long-practiced phenomenon of including precious metal in coins. And with that we finally got our "efficient media of exchange": pure IOUs recorded electronically.

We can think of money as the currency of taxation, with the money of account denominating one's social liability. I have to deliver a dollar's worth of commoditiesincluding labor power - to satisfy the public interest. Often, it is the tax that monetizes an activity - that puts a money value on it for the purpose of determining the share to render unto Caesar. The sovereign government names what money-denominated thing can be delivered in redemption against one's social obligation or duty to pay taxes. It can then issue the money thing in its own payments. That government money thing is, like all money things, a liability denominated in the state's money of account. And like all money things, it must be redeemed, that is, accepted by its issuer.

It's not money that the sovereign wants-she wants real resources. Money receipt is the tool, not the goal. If private creditors run the economy there just isn't enough power to produce left for the sovereign - for the public purpose. Government has an unlimited supply of its own 
money — but there have to be available productive resources. In modern economies that is not the usual constraint, however. Government's sovereign power is constrained in two main ways: arbitrary self-imposed budgetary constraints and exchange rate constraints.

Many countries happily impose both types_including Euroland. The handcuffs of budget limits were not enough—so they imposed the ball and chain of the Euro. We can observe the fall-out right now.

A sovereign government that issues its own currency faces no financial constraints. It cannot produce a financial imbalance. It can buy any resources that are for sale in terms of its own currency by using keystrokes. That does not mean it should try to buy all the resources it can-it can certainly produce inflation and it can leave too little resources to fulfill the private purpose. Government needs to use its sovereign power to move just the right amount of resources to serve the public purpose while leaving enough for the private purpose. That balance is mostly political. It is hard to find. I admit all that. But trying to use an arbitrary budget limit or supposed "balance" between tax receipts and monetary spending is the worst possible way I can conceive of trying to find the right balance between the public and private purposes. What it usually does in reality is to leave the resources unused-wasted-rather than to leave them for the private purpose.

Much better is to explicitly decide: what do we want government to do? What do we want our private sector to do? Do we have a sufficient supply of resources domestically plus what we can obtain externally to achieve both? If we don’t how can we expand capacity as needed? I'm not necessarily arguing for a planned economy as usually defined. But of course, all economies are planned, of necessity. The question is: by whom and for whom? These are the real issues; they are difficult, they are contentious. But they have almost nothing to do with the size of a budget deficit. It is worse than pointless to set a deficit ratio goal of 3 percent or 6 percent, and a debt ratio goal of 60 percent. It is counterproductive.

Let me turn to the other self-imposed constraint: pegged exchange rates. Adopting a gold standard, or a foreign currency standard (“dollarization” or “euroization”), or for that matter a Friedmanian money growth rule, or an inflation target is a political act that serves the interests of some privileged group. There is no "natural” separation of a government from its money. The gold standard was legislated, just as the Federal Reserve Act of 1913 legislated the separation of 
Treasury and Central Bank functions, and the Balanced Budget Act of 1987 legislated the ex ante matching of federal government spending and revenue over a period determined by the heavenly movement of a celestial object. Ditto the myth of the supposed independence of the modern central bank - this is but a smokescreen to hide the fact that monetary policy is run for the benefit of Wall Street and London and Frankfurt and Paris.

\section{SECTORAL BALANCES AND THE PROBLEMS OF EUROLAND}

Wynne Godley taught us about balances—-the sectoral balances. Take a look at the US case.

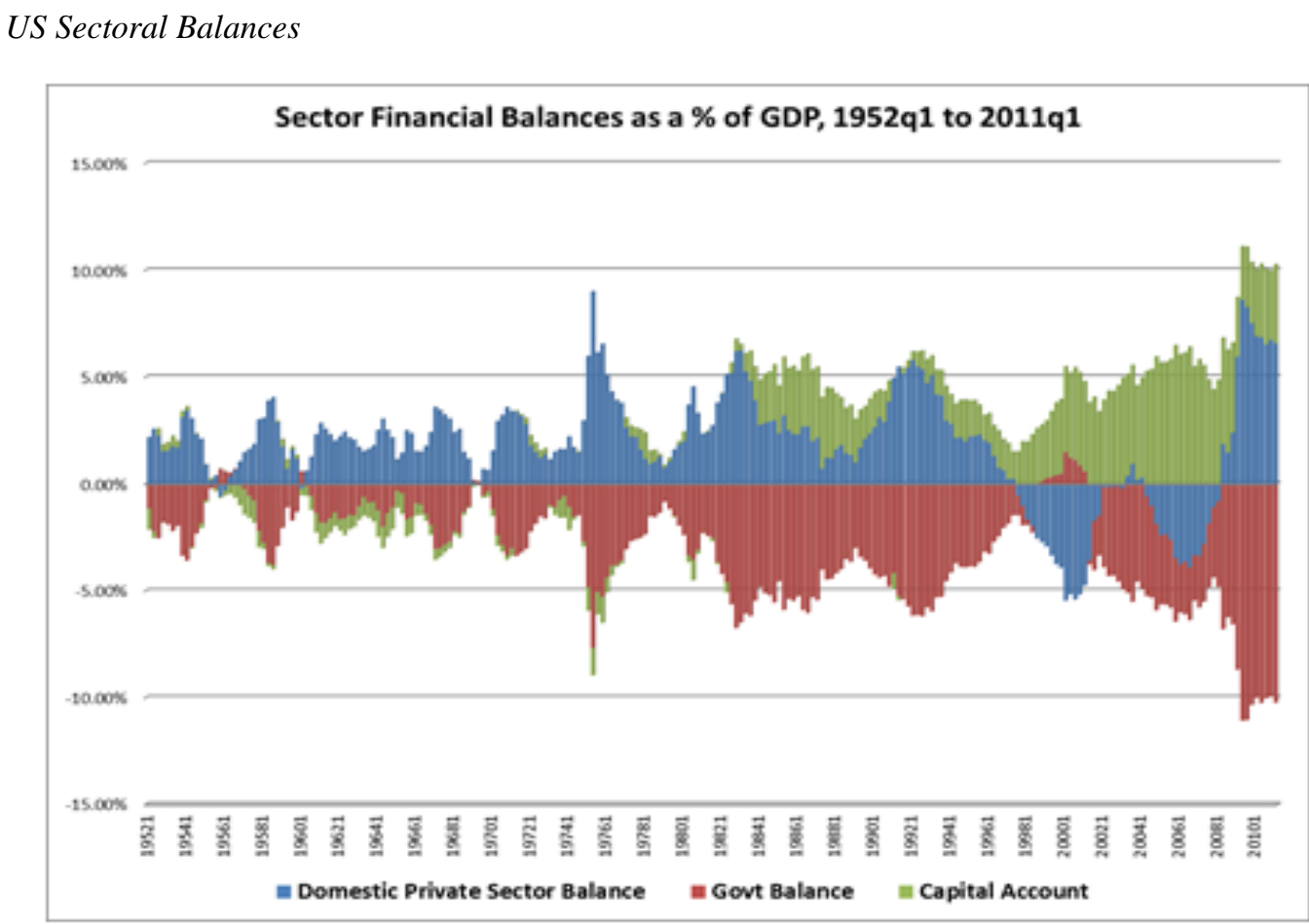

What do you see? Balance. A mirror image. In normal times, the private sector surplus plus the current account deficit equals the budget deficit. In the abnormal times of private sector deficits, we still saw balance- the government even ran budget surpluses for a few years to maintain the balance. Given a US current account deficit the sum of the US private and government sectors must be in deficit. But it balances.

Take a look at Euroland; what do you see? 


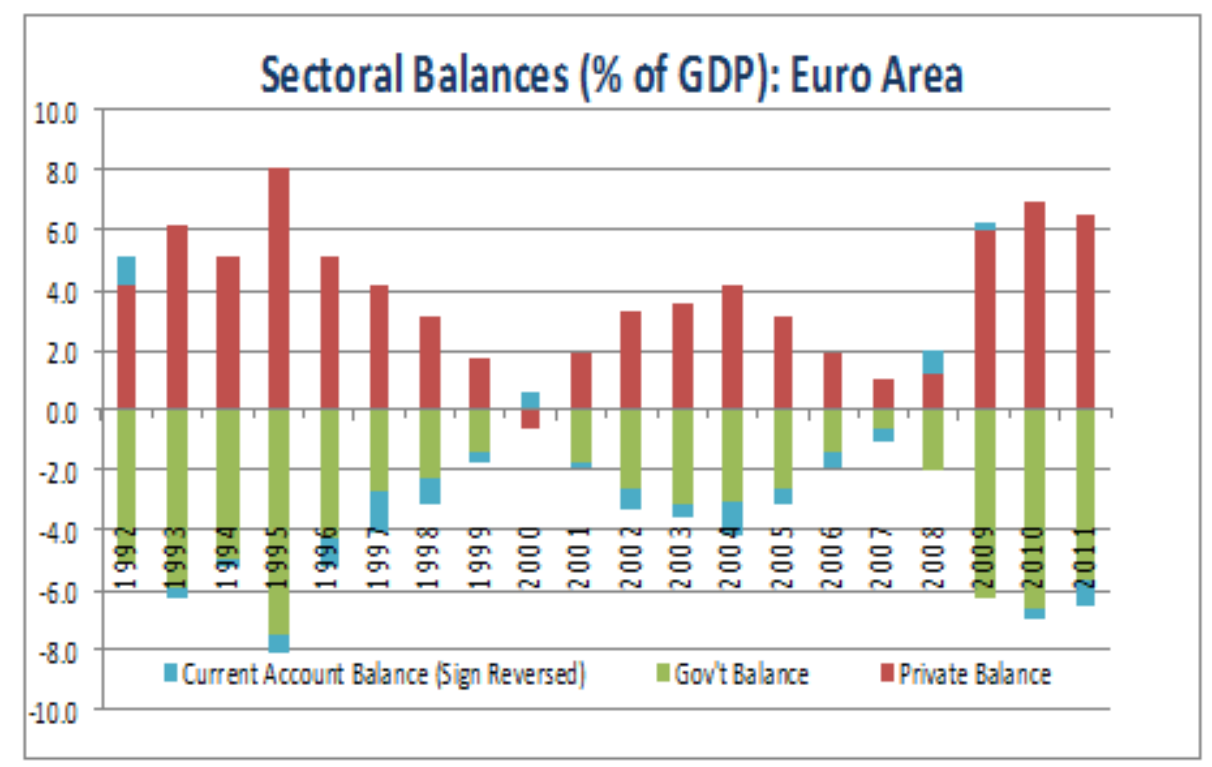

Balance. Isn't it amazing? Whenever the private sector surplus rises, the budget deficit rises; the correlation is near 100 percent, with the current account acting as the balancing item. Financial balances balance. If you take the world as a whole, there is no external sector since we don't trade with Martians. And so the sum of the global government deficits equals the sum of the private sector surpluses. It balances.

What's the problem in Euroland? Power. Private creditors in central Europe have too much of it; sovereigns on the periphery have too little. The creditors are starving the member states, aided and abetted by the euro, which usurped sovereign power and handed it over to the banking elite. But even still, the balances balance. You can curse the moon for its travels but it is still going to circumnavigate the globe. Admonish the Mediterraneans all you like for their budget deficits, but they still will have them compounded by the German export surpluses.

Germany has specialized in modern Mercantilistic dynamics that are well-suited to the way the European Monetary Union was set up. It has held the line on nominal wages while greatly increasing productivity. As a result, in spite of reasonably high living standards it has become a low-cost producer in Europe. Given productivity advantages it can go toe-to-toe against non-euro countries in spite of what looks like an overvalued currency. For Germany 
however, the euro is significantly undervalued — even though most euro nations find it overvalued. The result is that Germany has operated with a current account surplus (it accounts for three-quarters of all European Union trade surpluses) that allowed its domestic private sector and government to run deficits that were relatively small. Hence Germany's overall debt ratio is at 200 percent of GDP, approximately 50 percent of GDP lower than the eurozone average.

\section{Germany’s Sectoral Balances}

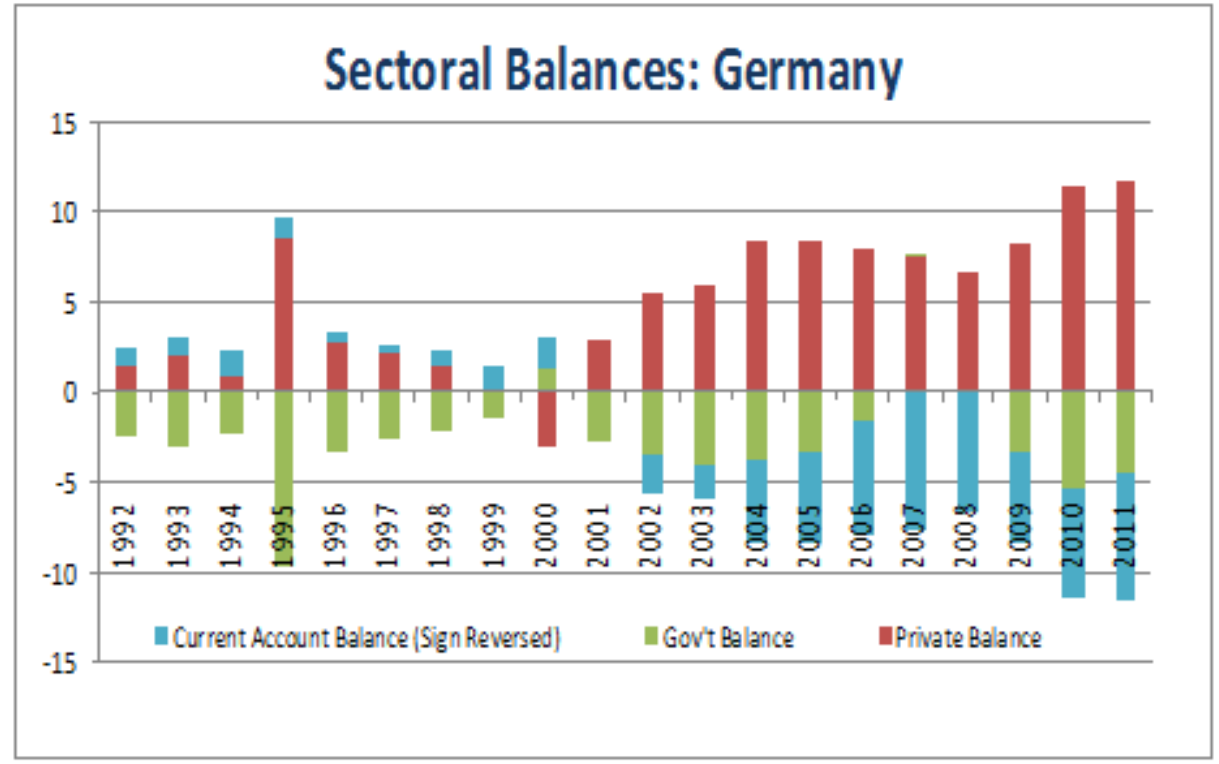

Those noncompetitive wages and prices among the rest of the EMU members almost guarantee current account deficits that in turn, by identity, guarantee rising debt-either by the government or by the private sector. And if debt grows faster than GDP, the debt ratio rises. Note that these are statements informed by identities; they are not meant to be policy statements. But policy cannot avoid identities. Reduction of deficits and debts in periphery nations require changes to balances outside the periphery. If we want Greece or Ireland to lower debt ratios they must change current account balances. That in turn requires that some nations reduce their current account surpluses. For example, if Germany would be willing to run large current account deficits, it would be easier for periphery nations to reduce domestic deficit spending.

Not surprisingly, the Godleyan balances identity hit the periphery nations particularly hard as they suffer from what is, for them, an overvalued euro and lower productivity than 
Germany enjoys. With current accounts biased toward deficits, it is not a surprise to find that the Mediterraneans have bigger government and private sector debt loads. Take a look at Italy. Given moderate private sector surpluses and growth of its current account deficit after German unification, it must have a government budget deficit. While its deficit is not large for a sovereign government, it is far too big for a country that has tied itself to a foreign currency.

Italy’s Sectoral Balances

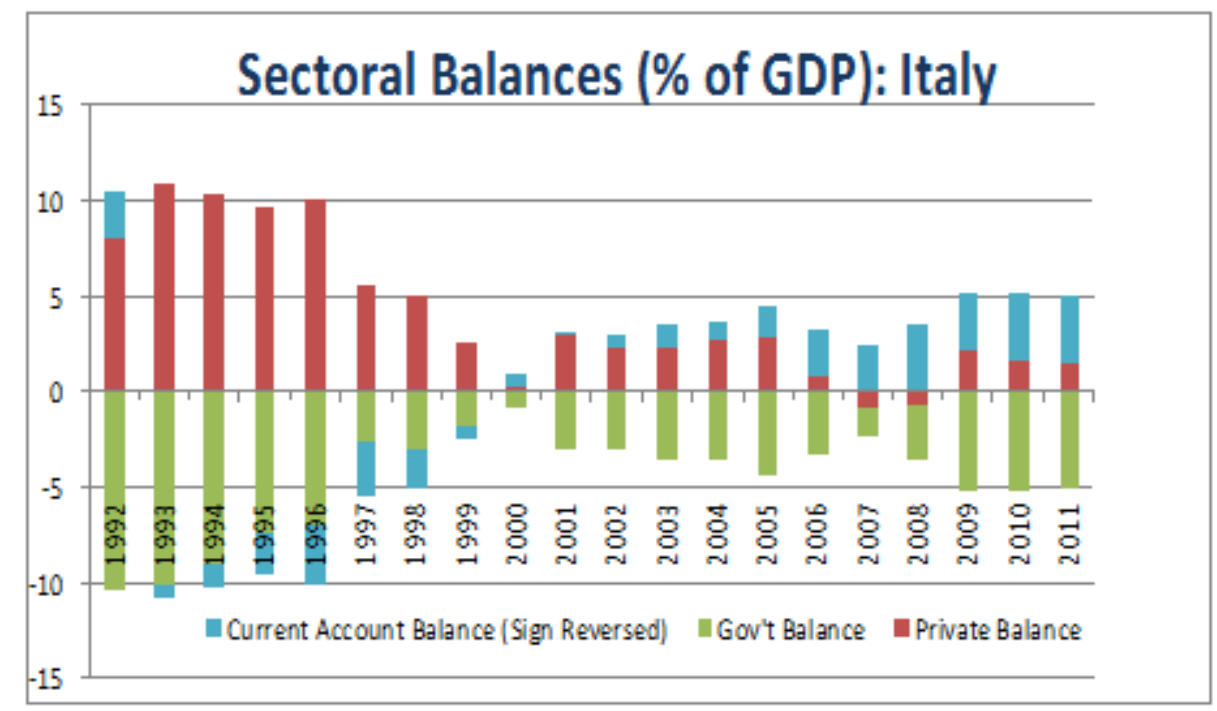

Spain is in even worse shape. While it was the paragon of "fiscal responsibility" before the crisis, this was made possible only because its private sector was willing to run deficits that would shame even a spendthrift American consumer. Combine that with a current account deficit, and the budget deficit was sure to blow up if the private sector ever reversed course and stopped borrowing. The Global Financial Crisis made that scenario a reality. 


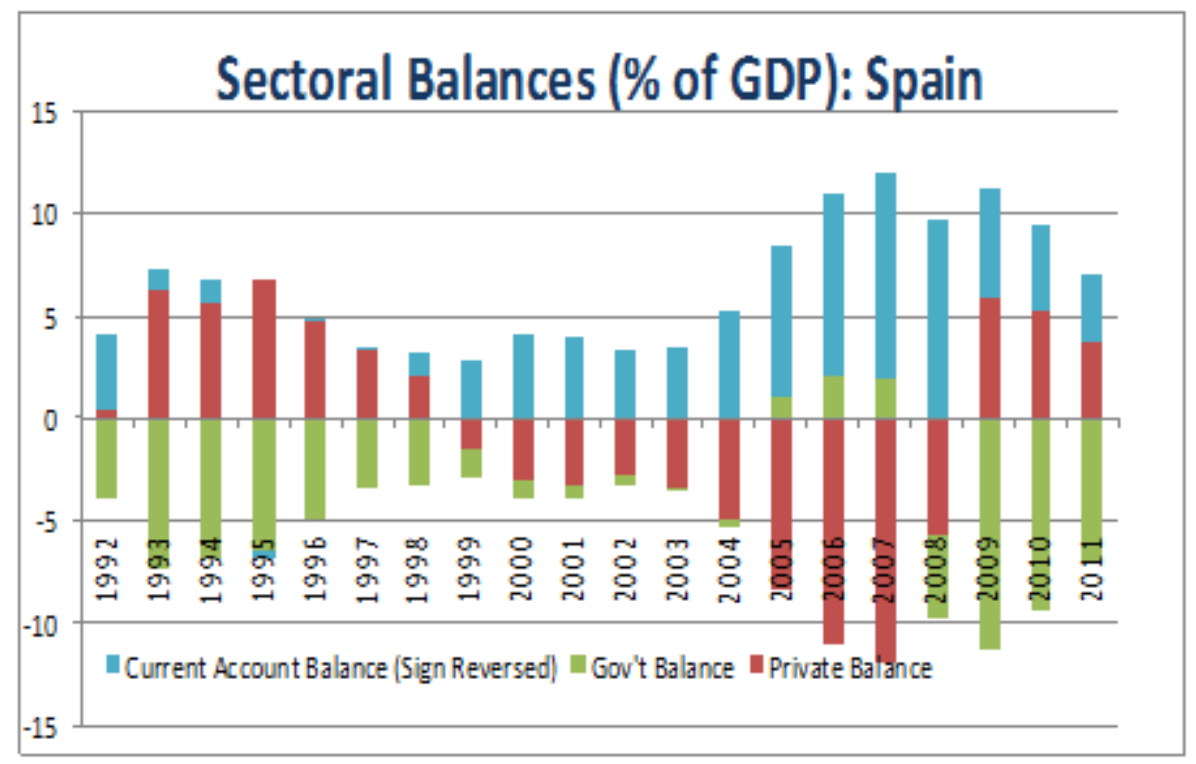

Now, if Europe's center understood balance sheets, it would be obvious that Germany's relatively “better” balances rely on the periphery’s relatively “worse” balances. If each had separate currencies, a partial solution would be to adjust exchange rates so that our debtors would have depreciation and Germany would have an appreciating currency. Since within the euro this is not possible, the only price adjustment that can work would be either rising wages and prices in Germany, or falling wages and prices on the periphery. But European Central Bank, Bundesbank and EU policy more generally will not allow significant wage and price inflation in the center. Hence, the only solution is persistent deflationary pressures on the periphery. Those dynamics lead to slow growth, at best, or even collapsing real GDP and income, and hence compound the debt burden problems.

We have known since the time of Irving Fisher that deflation imposes tremendous costs. The biggest cost is born by debtors as the "real" value of their nominally denominated debts increases. It is for this reason that deflation is a disease to be avoided-it typically results in debt deflation dynamics with debtors forced to default on commitments. Outside deep recessions or depressions, price and wage deflation is a rare event—and an outcome that policy purposely tries to avoid. But if Germany refuses to inflate and if the PIIGS 
(Portugal, Italy, Ireland, Greece and Spain) cannot depreciate their currencies, then debt deflation dynamics are the only way to avoid increasingly noncompetitive wages and prices.

\section{CONCLUSION}

The real imbalance is power.

And this isn't just a European disease. There is a generalized perception of a world out of balance. We've got Arab springs, Occupy Wall Street movements, and protests all over Europe. Why? Imbalances: everywhere I look in the Western world, the public sector is too small; we've privatized too many essential public sector functions - our arts, culture, prisons and punishment, military in Iraq, increasingly our education, our motor vehicle departments, our pensions. All privatized. Even responsibility for full employment. And supervision of our banks - we let them self-regulate, and even self-prosecute and self-punish.

What happens? Fraud, unemployment, inequality, poverty, and inadequate healthcare, retirement, and welfare. If you think about it, we chose the worst of all possible times to embark on the great neoliberal experiment-downsizing government, privatizing many of its functions, slashing the safety net. In the West, we are aging - which creates the twin problems of the need to devote more resources to aged care and, at the same time, a private desire to accumulate financial resources for individual retirements.

And that, in turn, led to the accumulation of unprecedented financial wealth under management by professionals. Current and future retirees demand higher returns to increase their security, and what Minsky called "money manager capitalism” responded by pouring more resources into the financial sector, doubling its share of value added, and capturing 40 percent of all corporate profits in the US.

It's too much. Finance is at best an intermediate good that might in the best of circumstances contribute to production. At the same time, financial wealth represents a potential claim on output but does not guarantee output will be available as needed. We need old folks' homes but finance is more interested in gambling on CDOs squared and cubed.

But it is worse than that. Modern finance, at least what is practiced at the biggest banks, is about fraud. So finance is not even a zero sum game-it largely makes a negative economic contribution. 
The imbalance is one of power-not financial imbalances. The disease is money manager capitalism. The symptom is the subprime frauds in the US, the austerity imposed on Greece and Ireland, the stagnation of incomes in most developed nations, the rising inequality and poverty in the midst of plenty, the growing despair and feelings of hopelessness.

There are no quick fixes, no magic bullets. The solution is not to slash government spending in Greece. Even reform of Maastricht rules plus bigger bailouts is not a solution. Nor can it be found in some new international monetary system based on a Bancor and run by the money manager neoliberals.

No, the reforms must be fundamental. They must be of Babylonian, even Biblical scale: cancel the debts of homeowners, of Mediterraneans and Irish and Icelanders, of students and credit card users and of the HIPCs (heavily indebted poor countries). Creditors must be downsized, bankrupted, wiped out. Fraudsters should be prosecuted and punished. The share of real income and wealth of the bottom 99 percent must be increased. The power of the European neoliberals must be vanquished, with the EMU either dissolved or reconstituted. The predator state has to be replaced with a government of the people operating for the public purpose. 


\section{REFERENCES}

Atwood, Margaret. 2008. Payback: Debt and the Shadow Side of Wealth. Toronto, Canada: House of Anansi Press, Inc.

Davidson, P. 1978. Money and the Real World. London, UK: Macmillan.

Godley, Wynne. 1996. "Money, Finance and National Income Determination: An Integrated Approach.” Working Paper No. 167. Annandale-On-Hudson, NY: Levy Economics Institute of Bard College.

Goodhart, Charles A.E. 1998. "Two concepts of money: implications for the analysis of optimal currency areas.” European Journal of Political Economy 14:407-432.

—. 2008."Money and Default.” In Mathew Forstater and L. Randall Wray (eds.) Keynes for the Twenty-First Century: The Continuing Relevance of the General Theory, 213223. New York, NY: Palgrave Macmillan.

Hudson, Michael. 1998. Bronze Age Finance, 2500-1200. Manuscript.

Ingham, Geoffrey. 2000. Babylonian Madness: On the Historical and Sociological Origins of Money. In John Smithin (ed.) What Is Money. London \& New York: Routledge.

— . 2004a. "The Emergence of Capitalist Credit Money.” In L.R. Wray (ed.), Credit and State Theories of Money: The Contributions of A. Mitchell Innes, 173-222. Cheltenham, UK: Edward Elgar.

— 2004b. The Nature of Money. Cambridge, UK: Polity Press Ltd.

Innes, A. M. 1913. “What is money?” Banking Law Journal 30(5): 377-408.

_ . 1914. "The Credit Theory of Money.” Banking Law Journal 31: 151-68. Reprinted in L. R. Wray (ed.) Credit and State Theories of Money, 14-49. Cheltenham, UK and Northampton, MA, USA: Edward Elgar.

Keynes, John Maynard. 1964. The General Theory of Employment, Interest and Money. New York, NY and London, UK: Harcourt Brace Jovanovich.

— 1976. A Treatise on Money. Volumes I and II. New York, NY: Harcourt, Brace \& Co.

—. 1914. "What is Money?”Economic Journal 24(95): 419-421.

Knapp, G. F. 1924. The State Theory of Money. Clifton, NY: Augustus M. Kelley.

Kurke, Leslie. 1999. Coins, Bodies, Games, and Gold. Princeton, NJ: Princeton University Press. xxi, 385.

Lerner, Abba P. 1943. "Functional Finance and the Federal Debt. Social Research 10: 38-51. 
—_. 1947. "Money As a Creature of the State.” American Economic Review 37: 312-317.

Minsky, Hyman P. 1986. Stabilizing an Unstable Economy. New Haven, CT: Yale University Press.

St. Augustine. "Sermon on the Mount, Harmony of the Gospels and Homilies on the Gospels: Nicene and Post-Nicene Fathers of the Christian Church, Part 6, (Sermon XL)." http://www.synaxis.org/cf/volume15/ECF00038.htm.

Wray, L. Randall. 1998. Understanding Modern Money: The Key to Full Employment and Price Stability. Northampton, MA: Edward Elgar.

- 1990. Money and Credit in Capitalist Economies: The EndogenousMoney Approach. Aldershot, UK and Brookfield, VT, USA: Edward Elgar.

- 2004. Credit and State Theories of Money. Cheltenham, UK and Northampton, MA,USA: Edward Elgar. 